\title{
Characterization of High-Producing Cows by their Immunogenetic Status
}

\author{
S.L. Gridina \\ Doctor of Sciences (Agriculture), principal researcher \\ Ural Federal Agrarian Scientific Research Centre \\ Agricultural Research Institute of Ural Branch of RAS, \\ 620061, Ekaterinburgr, 21, Glavnaya st, Russia
}

\author{
V.F. Gridin \\ Doctor of Sciences (Agriculture), principal researcher \\ Ural Federal Agrarian Scientific Research Centre \\ Agricultural Research Institute of Ural Branch of RAS, \\ 620061, Ekaterinburgr, 21, Glavnaya st, Russia
}

\author{
O.I. Leshonok \\ Candidate of Sciences (Agriculture), principal researcher \\ Ural Federal Agrarian Scientific Research Centre \\ Agricultural Research Institute of Ural Branch of RAS, \\ 620061, Ekaterinburgr, 21, Glavnaya st, Russia
}

\begin{abstract}
The selection of high-producing cows into the group of cows carrying bull calves is of great importance for successful breeding as for a single farm, as for the industry in the whole region. Present work analyses the productivity of the cattle herd in Sverdlovsk region. It was established that the percentage of cows with the yield of more than 7.0 tons of milk per lactation constantly increases. For instance, in $\mathbf{2 0 1 5}$, the percentage of such cows was $41.4 \%$, while by 2017 it increased up to $54.2 \%$. Considering generally increased milk yield, the farms have cows with record breaking yields. The absolute champion of 2017 is cow Snegurka 5242 which yield amounted to $17,120 \mathrm{~kg}$ of milk per one lactation with the mass fraction of fat of $3.90 \%$, mass fraction of protein of $3.25 \%$ and nutritional yield (fat + proteins) of $1223 \mathrm{~kg}$. The analysis of the high-producing cow genotype has demonstrated that the animals with I2D'E'3G'O' allele are characterized by the highest productivity. In the group of selected 2919 cows with the productivity of more than 10.0 tons of milk, 77 species have the yield of more than $11515 \mathrm{~kg}$ of milk regarding the maximum lactation. The most highly productive animals can have G2I2Y2E'3Q' allele, 180 animals (6.2\%) in the whole group. The determination of the alleles characterizing the immuno-genetic status of high-producing cows allows defining the potential productivi-ty of the offspring and, using this data as the basis, carrying out early estima-tion of animal productivity aimed at their selection into the group of cows car-rying bull calves.
\end{abstract}

\section{Keywords - cow, milk yield, lactation, milk, fat, protein}

\section{JUSTIFICATION OF THE STUDY}

The main purpose of cattle breeding is the solution of the food problem in the country, i.e. provision of food to people using accessible biological re-sources. Over the recent years, there has been a substantial increase in milk yield of cattle; however, the deficit of diary products remains [2-4, 14].
As a result of many-year work by crossing Ural cattle with Holstein spe-cies of different selections, a modern Black Pied Ural breed was developed. The animals of the new breed are of a pronounced milk-producing type and can consume and effectively process into milk a large amount of feeds, have strong feet and hooves and well adapted to machine milking $[1,5-9]$.

Currently, the selection of the best animals for further breeding is of great significance. Noteworthy, the attention should be paid to stock breeding of dairy cattle having larger longevity; a particular attention should be paid to the health of locally acclimated high-producing cows. This work should be per-formed only on the animals with confirmed origin [10-13, $15]$.

The research goal is to characterize the immunogenetic status of high-producing cows and make further early-age selection of cows carrying breed grading bulls on its basis.

\section{INVESTIGATION METHODS}

The study involved black pied cattle breed of breeding organizations hav-ing score cards of Sverdlovsk region, separate enterprises having high produc-ing animals and immunogenetic laboratory material of Ural Federal Agrarian Scientific Research Centre of the Ural Branch of RAS (Ural Agricultural Re-search Institute). In general, the data of dairy productivity and immunogenetic inspection of 2919 cows with the milk yield over 305 days of more than 10 tons were analyzed.Demand for energy resources continues to increase worldwide and accounts for $60 \%$ of growth since the early 1990s. In the face of stricter environmental requirements, consumers are more likely to use natural gas in general, including LNG. Over the past 25 years, the growth in demand for $\mathrm{LNG}$ as an energy carrier has been $2.3 \%$ per year. 


\section{INVESTIGATION RESULTS}

The breeding work, aimed at increased cattle milk yield using prominent genetic potential of Holstein breed, as well as improvement of feeding, stock-keeping and milking, constantly increases livestock population with high milk yield per lactation (Table 1, Fig. 1). For example in 2017, in the breeding en-terprises of Sverdlovsk region, as compared to 2016, the number of cows with the milk yield lower than 5.0 tons has decreased by 1004 heads. At the same time, an appreciable increase in cow population with the productivity of more than 7.0 tons of milk has increased up to 26,156 cows (by 2532 heads).

TABLE I. DYNAMICS OF COW DISTRIBUTION IN BREEDING ORGANIZATIONS OF SVERDLOVSK REGION IN TERMS OF MILK YIELD PER FINISHED LACTATION (HEADS/\%)

\begin{tabular}{|c|c|c|c|c|c|c|c|c|}
\hline \multirow{2}{*}{ Year } & \multirow{2}{*}{ Cows } & \multicolumn{7}{|c|}{ Cows with yield [kg] } \\
\cline { 3 - 9 } & & $<3000$ & $\begin{array}{c}3001- \\
4000\end{array}$ & $\begin{array}{c}4001- \\
5000\end{array}$ & $\begin{array}{c}5001- \\
7000\end{array}$ & $>7001$ & $\begin{array}{c}>7001 \text { with } \\
\text { mass fraction of fat }>4 \%\end{array}$ & $\begin{array}{c}>7001 \text { with } \\
\text { mass fraction of protein }>3 \%\end{array}$ \\
\hline \multirow{2}{*}{2015} & 56051 & 982 & 2882 & 7383 & 21569 & 23235 & 6271 & 19389 \\
\cline { 2 - 10 } & 100 & 1.8 & 5.1 & 13.2 & 38.5 & 41.4 & 11.2 & 41.1 \\
\hline \multirow{2}{*}{2016} & 47177 & 240 & 1475 & 4338 & 17500 & 23624 & 6172 & 46.4 \\
\cline { 2 - 10 } & 100 & 0.5 & 3.1 & 9.2 & 37.1 & 50.1 & 13.1 & 23919 \\
\hline \multirow{2}{*}{2017} & 48215 & 110 & 971 & 3968 & 17010 & 26156 & 7268 & 49.6 \\
\cline { 2 - 9 } & 100 & 0.3 & 2.0 & 8.2 & 35.3 & 54.2 & 15.1 & 49.6 \\
\hline
\end{tabular}

The trend of dairy products consumption testifies the increased interest of people to milk containing decreased fat content and increased content of protein. The analysis of stock data testifies that in breeding herds of Sverd-lovsk region, there is an increase of the population of cows with the yield of more than 7.0 tons of milk and mass fraction of protein of at least $3.0 \%$. Over the last three years, the number of such animals increased by 4530 heads and amounted to 23,919 cows, which is $49.6 \%$ of total population of cows in the herd $[1-3]$.

Considering the general increase of milk production and quality, a spe-cial attention should be paid to the selection of cows for the breeding nucleus; this is essential for successful breeding. This group conditionally includes most valuable animals that substantially exceed average indicators across the herd.

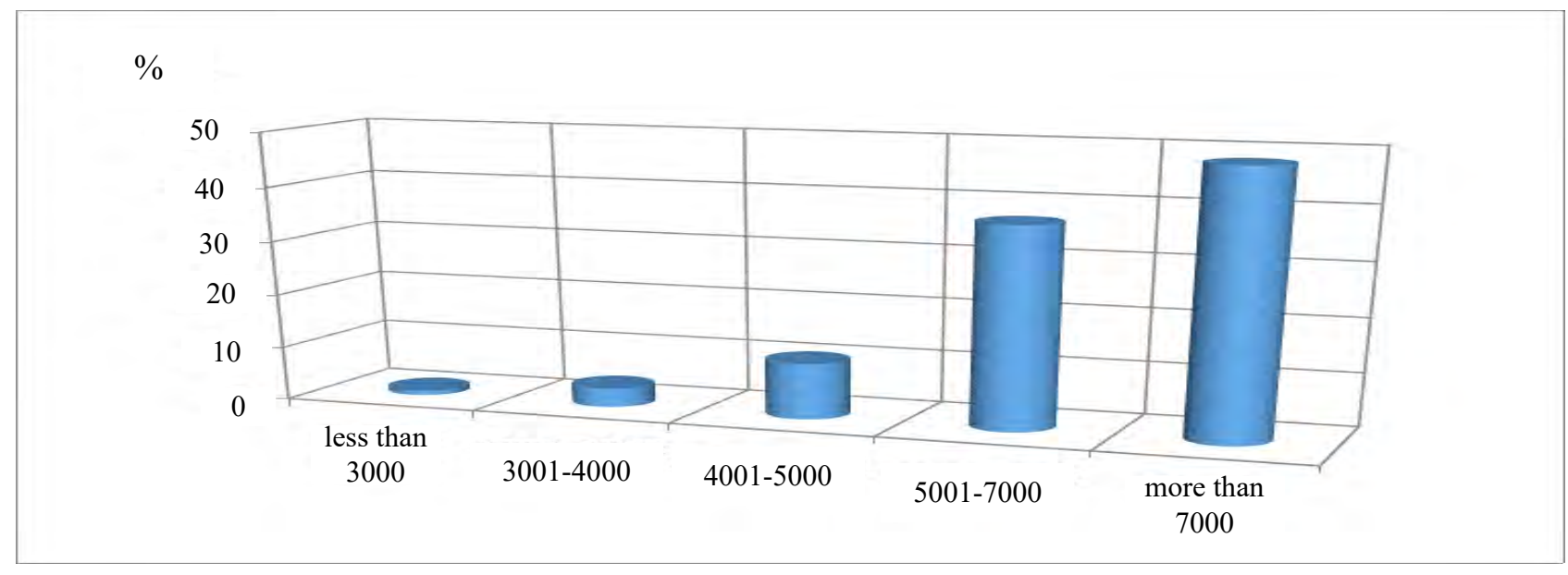

Fig. 1. Average data on distribution of cows in terms of milk yield (2015-2017) in \%t

$\mathrm{S}$

The analysis of stock cards shows that the number of highly productive cows constantly increases. Table 2 presents the data on the productivity of the most valuable cows of Sverdlovsk region having the milk yield of at least 15.0 tons over 305 days of lactation.
The absolute champion in the list is cow Snegurka 5242 that belongs to Closed Joint-Stock Company Agrofirma Patrushi. Snegurka 5242 over 3 lac-tations has produced $17,120 \mathrm{~kg}$ of milk with the mass fraction of fat of $3.9 \%$, mass fraction of protein of $3.25 \%$ and nutritional yield (fat + protein) of $1223 \mathrm{~kg}$. 
One more cow to mention is Lolita 2382. It is both highproducing cow and champion in terms of milk yield per fifth lactation. Over the usage time, Lolita 2382 has produced 59.7 tons of milk, three heifer calves and two bull calves.

High-producing cows are the breed's gold reserves and require particular attention in terms of management, feeding and stockkeeping. However, zoo-logic and veterinary experts can get real productivity indicators of the animals only at the age of at least 2.5 years. Thus, the estimation of prospective productivity is rational to be made at the earliest age possible.
One of these methods can be the discovery of alleles (genotype) connected with high produc-tivity and determination of the immunogenetic status of a young animal. In this connection, the immunogenetic status of highproducing cows of Sverdlovsk region was determined (Table $3)$. The table contains data from the largest da-tasets.

In total, 8658 cows were selected for the analysis with the yield of at least 10.0 tons of milk per lactation. Among them, 2919 cows have immuno-genetic origin assessment (Table 3 ).

TABLE II. HIGH-PRODUCING CHAMPION COWS OF SVERDLOVSK REGION

\begin{tabular}{|c|c|c|c|c|c|}
\hline Nickname & Lactation & Milk yield [kg] & $\begin{array}{c}\text { Mass fraction } \\
\text { of fat [\%] }\end{array}$ & $\begin{array}{c}\text { Mass fraction } \\
\text { of protein [\%] }\end{array}$ & Nutritional yield [kg] \\
\hline \multicolumn{7}{|c|}{ CJSC Agrofirma Patrushi } \\
\hline Snegurka 5242 & 3 & 17120 & 3.90 & 3.25 & 1223 \\
\hline Rodina 6384 & 2 & 16682 & 3.93 & 3.27 & 1201 \\
\hline Yavlina 4898 & 3 & 16525 & 3.97 & 3.28 & 1198 \\
\hline Basma 2120 & 2 & 16267 & 3.97 & 3.32 & 1185 \\
\hline Silva 3552 & 4 & 16025 & 4.04 & 3.26 & 1170 \\
\hline Lolita 2382 & 5 & 15628 & 4.02 & 3.24 & 1124 \\
\hline Riga 6608 & 2 & 15270 & 4.04 & 3.32 & 1118 \\
\hline Madonna 4644 & 3 & 15391 & 3.98 & 3.28 & 1117 \\
\hline Firma 5494 & 3 & 15526 & 3.97 & 3.23 & 1189 \\
\hline \multicolumn{7}{|l|}{ OJSC Sverdlovskaya ptitsefabrika } \\
\hline Maranta 8599 & 2 & 16329 & 4.05 & 3.23 & 1128 \\
\hline \multicolumn{7}{|l|}{} \\
\hline 122448 N & 3 & 16121 & 3.83 & 3.17 & \\
\hline
\end{tabular}

TABLE III. CHARACTERIZATION OF HIGH-PRODUCING COWSBY THE IMMUNOGENETIC STATUS

\begin{tabular}{|c|c|c|c|c|c|c|c|}
\hline \multirow[b]{2}{*}{$\begin{array}{c}\text { Number of } \\
\text { cows }\end{array}$} & \multicolumn{3}{|c|}{ First lactation } & \multicolumn{4}{|c|}{ Maximum lactation } \\
\hline & $\begin{array}{l}\text { Milk yield } \\
\quad[\mathrm{kg}]\end{array}$ & $\begin{array}{c}\text { Mass } \\
\text { fraction of } \\
\text { fat [\%] }\end{array}$ & $\begin{array}{c}\text { Mass } \\
\text { fraction of } \\
\text { protein }[\%]\end{array}$ & $\begin{array}{c}\text { Time } \\
\text { of usage }\end{array}$ & $\begin{array}{l}\text { Milk yield } \\
{[\mathrm{kg}]}\end{array}$ & $\begin{array}{c}\text { Mass } \\
\text { fraction of } \\
\text { fat }[\%]\end{array}$ & $\begin{array}{c}\text { Mass fraction } \\
\text { of protein } \\
{[\%]}\end{array}$ \\
\hline \multicolumn{8}{|c|}{ Total across the set } \\
\hline 2919 & 8870 & 3.89 & 3.16 & 2.6 & 11226 & 3.93 & 3.22 \\
\hline \multicolumn{8}{|c|}{$\mathrm{G}_{2} \mathrm{I}_{2} \mathrm{Y}_{2} \mathrm{E}_{3}^{\prime} \mathrm{Q}^{\prime}$ genotype } \\
\hline 180 & 8983 & 3.90 & 3.17 & 2.4 & 11251 & 3.92 & 3.22 \\
\hline \multicolumn{8}{|c|}{$\mathrm{G}_{2} \mathrm{Y}_{2} \mathrm{E}_{3} \mathrm{Q}^{\prime}$ genotype } \\
\hline 135 & 9131 & 3.89 & 3.16 & 2.3 & 11117 & 3.94 & 3.22 \\
\hline \multicolumn{8}{|c|}{$\mathrm{G}_{2} \mathrm{Y}_{2} \mathrm{D}^{\prime} \mathrm{E}_{3}^{\prime} \mathrm{G}^{\prime} \mathrm{O}^{\prime} \mathrm{Q}$ ' genotype } \\
\hline 83 & 9352 & 3.90 & 3.19 & 2.3 & 11380 & 3.92 & 3.23 \\
\hline \multicolumn{8}{|c|}{$\mathrm{I}_{2} \mathrm{D}^{\prime} \mathrm{E}_{3}^{\prime} \mathrm{G}^{\prime} \mathrm{O}^{\prime}$ genotype } \\
\hline 77 & 9270 & 3.90 & 3.19 & 2.3 & 11515 & 3.92 & 3.21 \\
\hline \multicolumn{8}{|c|}{$\mathrm{B}_{2} \mathrm{G}_{2} \mathrm{O}_{1} \mathrm{Y}_{2} \mathrm{D}^{\prime} \mathrm{E}_{3}^{\prime} \mathrm{Q}^{\prime}$ genotype } \\
\hline 76 & 8722 & 3.92 & 3.15 & 2.7 & 11052 & 3.99 & 3.20 \\
\hline \multicolumn{8}{|c|}{$\mathrm{B}_{2} \mathrm{I}_{2} \mathrm{O}_{1} \mathrm{~B}^{\prime}$ genotype } \\
\hline 73 & 8735 & 3.89 & 3.16 & 2.6 & 11066 & 3.94 & 3.19 \\
\hline \multicolumn{8}{|c|}{$\mathrm{I}_{2}$ genotype } \\
\hline 67 & 8436 & 3.90 & 3.17 & 2.7 & 11027 & 3.98 & 3.22 \\
\hline \multicolumn{8}{|c|}{$\mathrm{G}_{2} \mathrm{Y}_{2} \mathrm{~A}_{2}{ }_{2} \mathrm{E}_{3}^{\prime} \mathrm{Q}^{\prime}$ genotype } \\
\hline 51 & 8942 & 3.89 & 3.18 & 2.6 & 10907 & 3.91 & 3.22 \\
\hline
\end{tabular}

The analysis of data in Table 3 demonstrates that the largest group (180 heads) includes animals with G2I2Y2E'3Q' 
genotype. The cows in this group per the first lactation have milk yield of $8983 \mathrm{~kg}$ with the mass fraction of fat of $3.90 \%$ and mass fraction of protein of $3.17 \%$; the maximum lactation yield-ed $11,251 \mathrm{~kg}, 3.92 \%$ and $3.22 \%$, respectively.

The largest yield, both over the first and maximum lactation, was demonstrated by the animals with $\mathrm{I}^{2} \mathrm{D}^{\prime} \mathrm{E}$ ' $3 \mathrm{G}^{\prime} \mathrm{O}$ ' genotype. These cows yielded over the first lactation $9270 \mathrm{~kg}$ of milk with fats of $3.90 \%$ and protein of $3.19 \%$; the maximum lactation yielded $11,515 \mathrm{~kg}, 3.92 \%$ and $3.21 \%$, respec-tively.

Along with high production, an important factor of diary cattle breeding efficacy is the time of livestock usage. The analysis of Table 3 says that the high-producing cows are used at enterprises for 2.6 lactations on average. However, animals with I2 genotype are productive for 2.7. lactations, while cows with genotypes G2Y2E'3Q'; G2Y2D'E'3G'O'Q' and I2D'E'3G'O' for only 2.3 lactations.

\section{CONCLUSION}

Thus, the breeding work at agricultural enterprises of Sverdlovsk region is at high level, which is confirmed by the management of $48.2 \%$ of cows with the yield of more than 7000 kilograms of milk per single lactation with the in-crease in the milk yield up to $17,120 \mathrm{~kg}$. The identified interconnections of the immunogenetic status of cows with their productivity allow determining the possible high productivity of offspring at early stages. The most productive group of cows are animals with I2D'E'3G'O' genotype.

\section{References}

[1] O.V. Gorelik, O.P. Neverova, O.A. Vzdornova, "Estimation of different geno-types of cows in terms of milk yield and adaptivity to machine milking (in Russian)", Proc. of Scientific conference of the Institute of veterinary medicine, pp. 40-48, 2018 [Urgent problems of biotechnology and veterinary medicine: theory and practice, Chelyabinsk, Russia, 2018]

[2] S.L. Gridina, V.F. Gridin, V.S. Mymrin, N.N. Zezin, Assessment of breeding and production properties of black pied livestock in regions and republics of Ural in 2015, Ekaterinburg, 2016, p. 74.
[3] S.L. Gridina, V.F. Gridin, V.S. Mymrin, N.N. Zezin, Assessment of breeding and production properties of black pied livestock in regions and republics of Ural in 2016, Ekaterinburg, 2017, p. 63

[4] S.L. Gridina, V.F. Gridin, V.S. Mymrin, N.N. Zezin, I.V. Tkachenko, Charac-teristics of breeding and production properties of black pied livestock in re-gions and republics of Ural, Ekaterinburg, 2018, p. 79..

[5] S.N. Izhboldina, M.R. Kudrin, V.L. Korobeynikova, "Morphological attributes and functional properties of udder of Holsteinized cows under conditions of Udmurt Republic", Bulletin of State Agricultural Academy, 2017, vol. 51, No. 2, pp. 8-16.

[6] O.I. Leshonok, "Impact of hereditary factors on the milk yield of Ural first-calf cows", Agrofood policy of Russia, 2014, No. 4, p. 33

[7] O.I. Leshonok, S.N. Siromakha, "Milk yield of livestock of different genotypes in Sverdlovsk region", Proc. of the Int. Conf., pp. 69-71, 2011 [Development strategy of food production under changing global climatic conditions and im-plementation of local breeding achievements, Ekaterinburg]/

[8] T.L Leshchuk., G.E. Uskov, "Breeding results of dairy cattle in Kurgan re-gion", Proc. Int. Scientific-Practical Conf., pp. 814-818, 2018 [Scientific sup-port of innovative development of agricultural industry in RF regions, Kurgan, 2018]

[9] O.G. Loretts, O.S. Chechenikhina, O.A. Bykova et al, Increased productive longevity of black pied cows, Ekaterinburg, 2017, pp. 15-25.

[10] A.I. Lyubimov, E.N. Martynova, G.V. Azimova, "Estimation of milk yield of cows from new family group of black pied breed in JSC Uchkhoz Iyulskoye Izhevskoy GSKhA", Proc. of the Int. ScientificPractical. Conf., 2018, pp. 73-74 [Innovative technologies for the program implementation of scientific and technological development of agricultural sector, Izhevsk, 2018

[11] I.V. Tkachenko, V.F. Gridin, S.L. Gridina, "Identification of the interconnec-tion between the productivity of Ural cows and immune status", Theory and practice of world science, 2017, No. 10, pp. 69-72.

[12] O.S. Shatalina, "Associations between the blood type and reproductive indica-tors of cattle", Agricultural Biology, 2018, No. 2, pp. 309-317.

[13] O.S. Shatalina, S.L. Gridina, "Interconnection between milk yield and calving interval of black pied cows", Agrifood policy of Russia, 2014, No. 9 , p. 53.

[14] V.Yu. Yakimova, E.N. Martynova, Impact of local and foreign seed bulls on the milk yield of offspring cows, Proc. of the Int. Conf., 2017, pp. 149-151[All-Russian Scientific and Practical conference. Ministry of Agriculture of the RF, Izhevsk SAA, Izhevsk, 2017]

[15] O.S. Chechenyhina, O.G. Loretts, O.A. Bykova, E.V. Schatskikh, V.F Gridin, L.Yu. Topuria, "Productive Qualities of Cattle in Dependence on Genetic and Paratypic Faktors", International Journal of Advanced Biotechnology and Re-search, 2018, vol. 9, No. 1, pp 586-593. 